\title{
Comparative Study on performance of concrete with Natural sand and Robo sand
}

\author{
P. Bhanu Prakash Reddy ${ }^{\# 1}$, V.Sowjanya Vani ${ }^{* 2}$, N.Sunil ${ }^{\# 3}$ \\ ${ }^{\# 1}$ PG Student, Department of Civil Engineering, GITAM University, Visakhapatnam, Andhra Pradesh, India \\ bhanu.bhanu.prakash16@gmail.com \\ ${ }^{* 2}$ Assistant Professor, Department of Civil Engineering, GITAM University, Visakhapatnam, Andhra Pradesh, \\ India \\ sowji.vani@gmail.com \\ ${ }^{\# 3}$ Assistant Professor, Department of Civil Engineering, GITAM University, Visakhapatnam, Andhra Pradesh, \\ India \\ nsunil1987@gmail.com
}

\begin{abstract}
Concrete Utility is increasing day by day in construction works. Generally, river sand is most used as fine aggregate in concrete for construction. River sand is becoming scarce due to the continuous mining of river beds. Also mining of sand from river bed is causing a lot of problems in environment. In this present experimental study natural sand is $100 \%$ replaced with manufactured sand or Robo Sand. The 28-days compressive strength and Durability of M30 grade concrete is determined. Acids considered for immersion of concrete cubes are $5 \%$ hydrochloric acid(HCL) and $5 \%$ Magnesium Sulphate(MgSO4) by weight of water for a period of 28-days. It is observed that compressive strength of Robo Sand is to be higher about $\mathbf{2 6 . 4 8 \%}$ when compared to natural sand. Further Robo sand concrete resulted higher resistance to chloride attack than Conventional Concrete. Further when it is immersed in Magnesium Sulphate solution no strength loss is observed. From the study it is finally concluded that Robo sand concrete performed better than conventional concrete in durability aspect.
\end{abstract}

Keyword- Robo sand concrete, Conventional concrete, Compressive strength, Durability, acid attack, Sulphate attack

\section{INTRODUCTION}

Fine aggregate is the one of main constituents of concrete. It is about $35 \%$ of volume of concrete. Natural sand as fine aggregate is mainly constituted from river beds. It always contains high percentage of organic materials, chlorides, sulphates, and silt which may affect the strength and durability. Quarrying sand from river bed in excess quantity is hazardous to environment. The deep pits dug in the river bed, affects the ground water level resulting unsustainable environment. The fine aggregate used must be of proper gradation $(4.75 \mathrm{mmto}$ $150 \mu$ ). In fine aggregate particles below 600 microns must be at least $30 \%$ to $50 \%$ for making good concrete. When fine aggregate proportioned properly it will result in well grading with minimum voids. It is the suitable substitute for river sand. These Requirements can be made possible in manufactured sand when compare to naturally available river sand.

Natural sand from river beds does not contain the fine particles in proper proportion. Presence of other impurities such as coal, bones, shells, mica and silt etc., makes it inferior for the use in cement concrete. Disintegration of these materials due to weathering process reduces the strength of concrete. Present days government is imposing many rules on the digging of natural sand from river beds. Further the naturally available sand is depleting very fast due to increase construction aspects.

Hence it is necessary to find an alternative material. The alternative material replacing natural sand partially or completely in concrete, should perform better without compromising the quality of concrete. In this respect the usage of Robo sand (artificial sand) in concrete is studied for its strength and durability. Robo sand for the present study is manufactured from standard crushers.

The study on strength and durability of concrete made by using manufactured sand is increasing day by day due to huge demand in construction industry. R. Ilangovana et al., (2008) [1] investigated strength and durability properties of concrete by replacing the fine aggregate with quarry dust. M20, M30, M40 grade concrete specimens are cast by using concrete cubes and beams with quarry dust concrete and normal sand concrete. Tests are conducted to determine the workability, compressive strength, drying shrinkage, water absorption test and also durability by immersing the cubes in $\mathrm{MgSO}_{4}$ and $\mathrm{H}_{2} \mathrm{SO}_{4}$ for a period of 28 days curing. In water permeability test, found that the quarry dust concrete is having low permeability when compared to conventional concrete in compressive strength test and flexural strength and found that quarry dust concrete 
increase in strength $10-12 \%$ when compared to conventional concrete. Finally the investigation concluded that $100 \%$ replacement of fine aggregate with quarry dust is possible. A. Priyanka Jadhava, and K. Dilip Kulkarni,, (2012) [2] studied the effect of replacement of natural Sand by manufacture sand on the properties of cement mortar. The mortar proportions are 1:2, 1:3 and 1:6 with water cement ratio as 0.5 and 0.55 . Therefore, the Robo Sand has a potential to provide alternative to natural sand and helps in maintaining the environment as well as economical balance. R. Vinayak Supekar, and D. Popat Kumbhar's, (2012) [3] studied the properties of concrete by replacement of natural sand with Artificial sand by $60 \%$. This resulted in producing artificial sand concrete of satisfactory workability and strength properties. The replacement of natural sand with artificial sand will help in conserving the natural resources as well as maintain ecological balance.

V. Bhikshma et al. (2010) [4] investigated flexural behaviour of high strength concrete with manufactured sand. In experimental work they casted concrete beams replacing different percentages of fine aggregate with Robo sand $(0 \%, 25 \%, 50 \%, 75 \%, 100 \%)$ by using super plasticizer. From the results it is reported that compressive strength of concrete increased as the the percentage of Robo sand increased. Similarly their increased flexural strength also. Finally it is concluded that manufacture sand can be used as alternative material to the natural sand. Priyanka, A. Jadhav, and Dilip, K. Kulkarni, (2012) [5] studied on an Experiment investigation on the properties of the concrete containing manufacture sand. In experimental work they casted concrete cubes, beams, cylinders with by replacing of fine aggregate with Robo Sand of varying percentages $(0 \%, 20 \%, 40 \%, 60 \%, 80 \%, 100 \%)$ and with different water cement ratio $0.4,0.45,0.5,0.55$ and conducted compressive strength, flexural strength, split tensile strength to the concrete specimens. It is observed that ideal replacement of fine aggregate with manufacture sand is $60 \%$. Finally it is concluded that concrete with manufactured sand gives better finishing when compared to conventional concrete.

S. Sudhir Kapgate, and S. R. Satone (2013) [6], studied on the effect of quarry dust as partial replacement of sand in concrete. In the experimental work concrete cubes, beams, cylinders are casted by replacing with different replacement levels of quarry dust $(0 \%, 20 \%, 25 \%, 30 \%, 35 \%)$ conducted compressive strength, flexural strength, split tensile strength test and compaction factor test to the concrete specimens. In experimental program it is observed that aggregates with higher surface area require more water to wet the surface of particle in order to maintain specific workability. Obviously increase in water content in mixture will adversely affect the quality of concrete. Finally it is concluded that the quarry dust is an alternative material to the sand.

The objectives of the present study is to study the strength and durability characteristics of Robo sand concrete and conventional concrete considering acid attack and Sulphate attack and compare the performance Robo sand concrete and conventional concrete in aggressive environment.

The scope of the study is to assess the use of robo sand in place of natural sand in concrete.

\section{MATERIALS USED IN CONCRETE}

\section{A. Cement}

Portland Pozzolana Cement conforming to IS 1489-1991[7] is used in the present study. The properties of the cement are tabulated in table 1 .

\section{TABLE 1 PROPERTIES OF CEMENT}

\begin{tabular}{|c|c|c|c|}
\hline S.NO. & Particulars of test & Test results & $\begin{array}{c}\text { Requirement as per } \\
\text { IS Code }\end{array}$ \\
\hline 1 & Fineness of cement & $97 \%$ & IS 1489-1991[7] \\
\hline 2 & Standard Consistency & $31 \%$ & IS 1489-1991[7] \\
\hline 3 & Setting time & & \\
\hline a & Initial setting time & $70 \mathrm{~min}$ & IS 1489-1991[7] \\
\hline b & Final setting time & $240 \mathrm{~min}$ & IS 1489-1991[7] \\
\hline
\end{tabular}

\section{B. Fine Aggregate}

The fine aggregate used in this study is natural sand and robo sand as per requirements of IS 383-1970[8]. The Robo sand is manufactured from Vertical Shaft Impactor (V.S.I) using granite aggregate. The properties of fine aggregate are determined based on tests recommended IS 2386-1968[9]. The results are tabulated in table 2.

TABLE 2 PROPERTIES OF FINE AGGREGATE

\begin{tabular}{|c|l|c|c|}
\hline S.NO. & Particulars of test & Natural Sand & Robo Sand \\
\hline 1 & Specific gravity & 2.65 & 2.61 \\
\hline 2 & \% Bulking of aggregates & 23.7 & 25.24 \\
\hline 3 & Fineness modulus & 2.88 & 3.0 \\
\hline 4 & Sieve analysis & Zone II & Zone II \\
& & IS 383-1970[8] & IS 383-1970[8] \\
& & & \\
\hline
\end{tabular}




\section{Coarse Aggregate}

In the present investigation crushed stone aggregate of $20 \mathrm{~mm}$ size is used. The properties of coarse aggregate are tabulated in table 3 . The coarse aggregate is used in saturated surface dry condition.

\section{TABLE 3 PROPERTIES OF COARSE AGGREGATE}

\begin{tabular}{|c|l|c|}
\hline S.NO. & Particulars of test & Test results \\
\hline 1 & Specific gravity & 2.68 \\
\hline 2 & Crushing value & $17.2 \%$ \\
\hline 3 & Impact value & $20.5 \%$ \\
\hline 4 & Fineness modulus & $3.02 \%$ \\
\hline
\end{tabular}

\section{Water}

In present study, potable water conforming to IS 3025-1986 [10] is used.

\section{E. Mix Design}

The mix design of the concrete is done as per IS 10262-2009[11]. For the present study, final proportions are concluded by casting several trails batch of concrete which is the tabulated in table 4 .

TABLE 4 MIX DESIGN FOR M30 GRADE CONCRETE

\begin{tabular}{|c|c|c|c|}
\hline Cement & $\begin{array}{c}\text { Fine } \\
\text { Aggregate }\end{array}$ & $\begin{array}{c}\text { Coarse } \\
\text { Aggregate }\end{array}$ & $\begin{array}{c}\text { Water to } \\
\text { Cement ratio }\end{array}$ \\
\hline $\begin{array}{c}395 \\
\left(\mathrm{Kg} / \mathrm{m}^{3}\right)\end{array}$ & $685\left(\mathrm{Kg} / \mathrm{m}^{3}\right)$ & $1114\left(\mathrm{Kg} / \mathrm{m}^{3}\right)$ & $186\left(\mathrm{Kg} / \mathrm{m}^{3}\right)$ \\
\hline 1 & 1.7 & 2.8 & 0.5 \\
\hline
\end{tabular}

\section{III.EXPERIMENTAL STUDY}

Concrete of M30 grade is prepared with help of obtained Mix Proportions by using Natural sand and Robo Sand. The Concrete Specimens are 100 x 100 x $100 \mathrm{~mm}$ in size.

Initially cement, fine aggregate, coarse aggregate, weighed accurately. These ingredients mixed in Pan mixer for 2 minutes [12]. Cubes are casted with the help of table vibrator. The casted cubes are demoulded and cured for a period of 28 days. Specimens are immersed in HCL solution and MgSo4 to determine acid attack and Sulphate attack on concrete as shown in Fig.1 after weighing. Concentration is 5\% for HCL by weight of water with $\mathrm{pH}$ about 2[13] and 5\% for MgSo4 by weight of water with $\mathrm{pH}$ about 6.4-6.9[13]. $\mathrm{pH}$ is maintained throughout the curing period. After 28 days of immersion, the concrete cubes are taken out of curing and tested for their compressive strength as per IS 516-1959 [14] in compression testing machine as shown in Fig. 2. Specimens are weighed prior to testing.

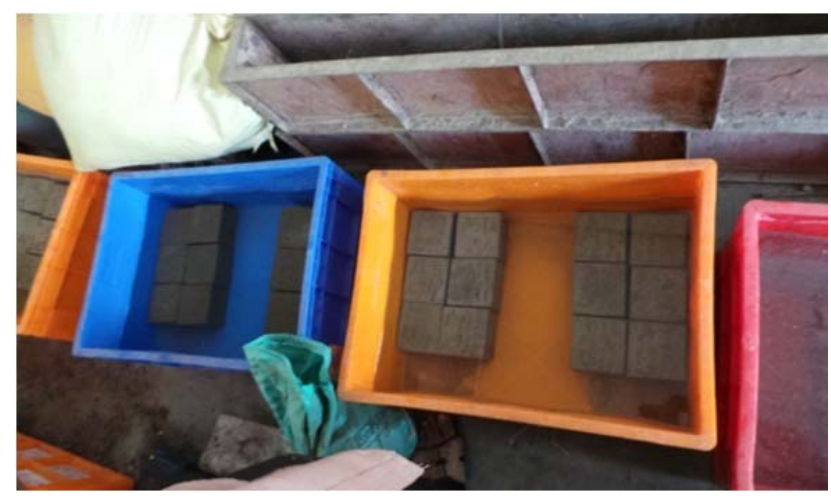

Fig. 1. Immersed Concrete specimens 


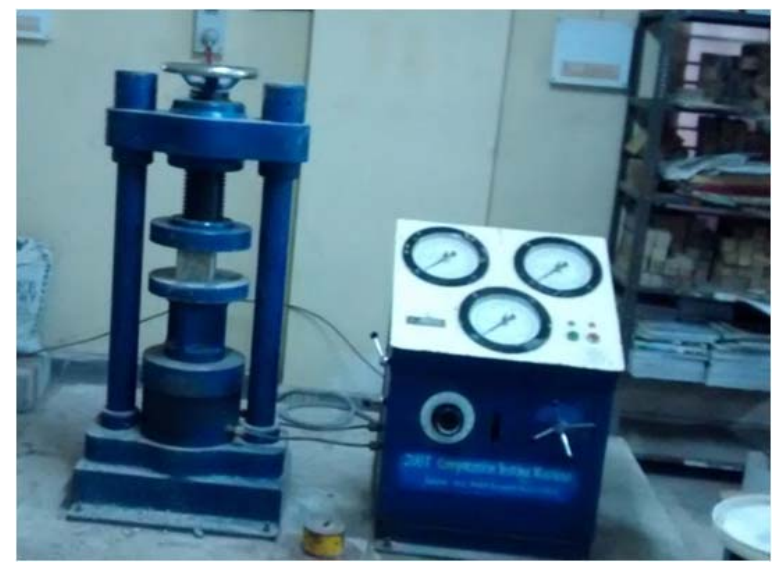

Fig. 2. Specimen under compression in Compression Testing Machine

\section{IV.RESULTS AND DISCUSSIONS}

Detailed discussions are made on obtained results (Compressive Strength, Weight loss, Acid attack and Sulphate attack) from the experimental work.

\section{A. Compressive Strength}

Plot 1 28-days Compressive strength of Robo sand and Conventional concrete

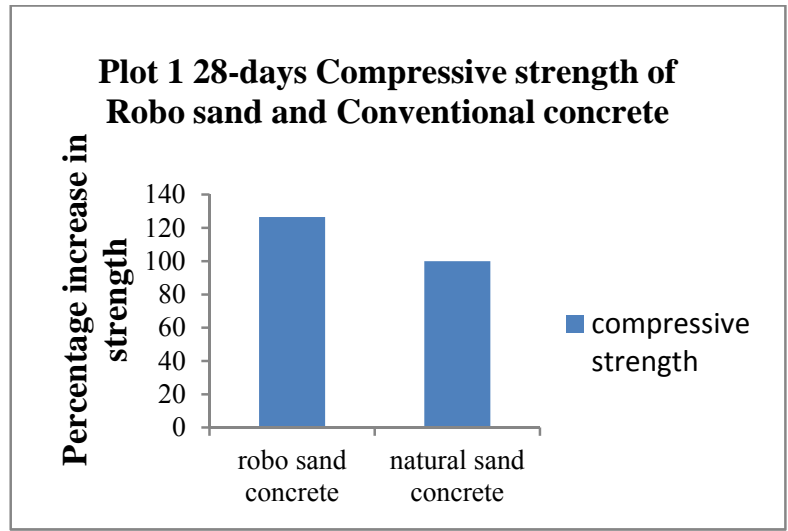

From Plot 1 it is observed that the compressive strength of robo sand concrete is more when compared to conventional concrete. The improvement in compressive strength is as high as $26.48 \%$. The increase in compressive strength is due to the sharp edged particles of robo sand providing better bond with the cement than rounded natural aggregate. This contributes to better binding effect with available cement paste improving compressive strength of concrete. Robo sand particles also give better packing due to high fineness modulus and cubic gradation. This leads to densification of paste by reducing pores and increase in strength.

\section{B. Effect of Acid on Concrete}

Plot 2 Percentage weight loss due to immersion of specimens in HCL solution for 28-days 


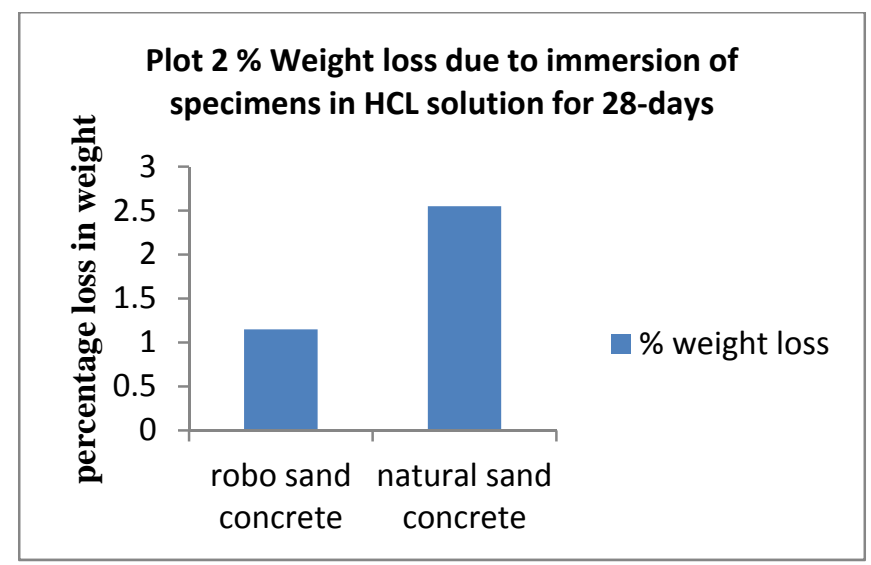

From Plot 2 it is observed that the weight loss in conventional concrete is $2.55 \%$ where as in robo sand concrete it is $1.15 \%$. Low percentage of weight loss in robo sand concrete may be due to lesser permeability as of lesser voids.

Plot 3 Percentage loss in Compressive Strength of specimens after 28-days acid attack

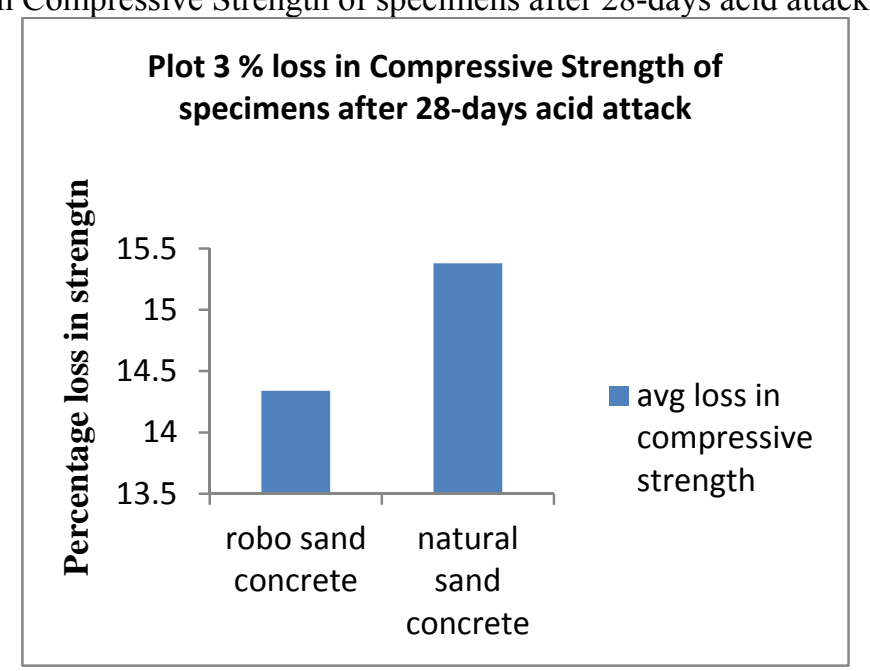

From Plot 3 it is observed that loss of compressive strength in conventional concrete is $15.18 \%$ and slightly lower in robo sand concrete which is $14.34 \%$. This indicates that higher acidic action takes place in conventional concrete. The observed compressive strength of acid attacked Robo Sand concrete is $7.36 \%$ higher when compared to natural sand concrete or conventional concrete when immersed in HCL and observations are similar to the findings of Shaikh, M. G. and Daimi, S.A. [15]. Acid attack takes place through porosity of concrete which is related to void ratio. Void ratio is higher in conventional concrete than robo sand concrete. The higher packing efficiency is achieved in robo sand indicating lesser permeability. Hence acid resistance is more in robo sand concrete.

C. Effect of Sulphate on Concrete

Plot 4 Percentage weight loss due to immersion of specimens in Magnesium Sulphate for period of 28-days 


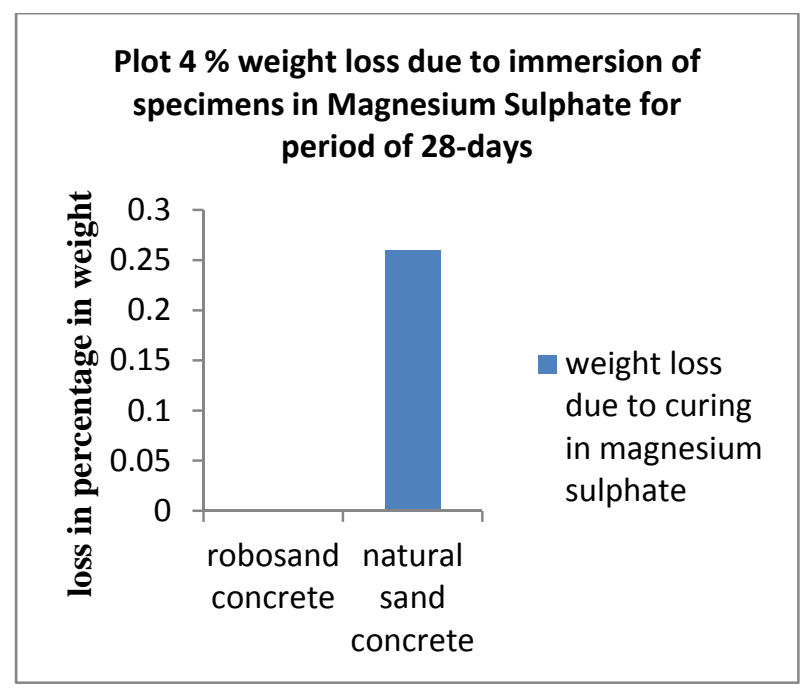

From Plot 4, there is no weight loss observed in robo sand concrete specimens immersed in magnesium sulphate solution for period of 28 days. For conventional concrete the weight loss is $0.25 \%$. These indicates that Robo sand does not impart Sulphate attack while natural sand does.

Plot 5 Percentage loss of compressive strength due to immersion of specimens in Magnesium Sulphate for period of 28-days

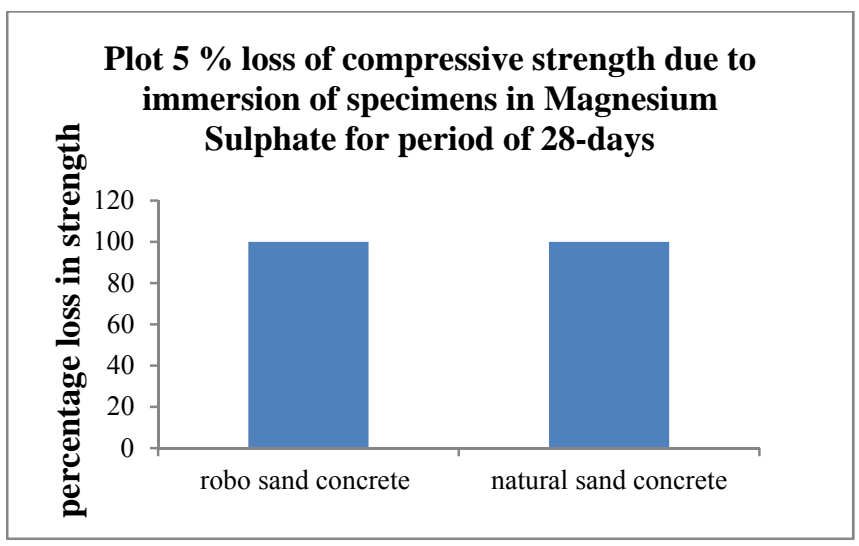

From Plot 5 it is observed that there is no loss in compressive strength for robo sand concrete and conventional concrete. It may be due to the reaction between sulphate and cement constituents of concrete results in conversion of calcium hydroxide to calcium sulphate (gypsum) which, in turn may be converted to sulfoaluminate.

\section{CONCLUSION}

From the experimental study it is concluded that

[1] Robo sand concrete resulted $26.48 \%$ increase in compressive strength when compared to conventional concrete.

[2] Weight loss in HCL solution is $1.150 \%$ and $2.55 \%$ robo sand concrete and natural sand concrete in respectively.

[3] Loss in compressive strength of robo sand concrete is $14.34 \%$ and natural sand concrete is $15.18 \%$ due to acid attack.

[4] Percentage weight loss is negligible in Robo sand concrete and $0.25 \%$ in conventional concrete.

[5] There is no loss in compressive strength for both concrete after immersion in MgSO4 solution.

Robo Sand concrete is slightly superior to Conventional concrete in durabilities. Hence Robo sand can be alternative to natural sand. 


\section{REFERENCES}

[1] R. Ilangovana, N. Mahendrana, K. Nagamanib, "Strength and Durability Properties of Concrete Containing Quarry Dust as Fine Aggregate", APRN Journal of Engineering and Applied Sciences,Vol. 3(5), 2008, p. 20-26. www.aprnjournals.com.

[2] A. Priyanka Jadhav and K. Dilip Kulkarni, "Effect of replacement of natural Sand by manufacture sand on the properties of cement mortar", International Journal and structural Engineering Technology, Vol.3 (2), 2012, p. 101-104.

[3] R. Vinayak Supekar and D. Popat Kumbhar, "Properties of concrete By Replacement Of Natural sand With Artificial sand", International Journal of Engineering Research \& Technology, Vol. 1(7), 2012, p. 1-7.

[4] V. Bhikshma, R. Kishore, C. V. Raghupathi," Investigation on flexural Behaviour of high strength manufactured sand concrete", Challenges Opportunities and solutions in structural engineering, 2010, p. 511-514.

[5] A. Priyanka Jadhav and Dilip Kulkarni, "An Experiment Investigation On The Properties Of the Concrete Containing Manufacture Sand", International Journal of Advanced Engineering Technology, Vol.3 (2), 2012, p. 101-104.

[6] S.Sudhir Kapgate and S.R.Satone, "Effect of Quarry dust As Partial Replacement of Sand In concrete", Indian Streams Research Journal, Vol.3 (5), 2013, p.1-7.

[7] IS 1489: 1991, Portland Pozzolona Cement Specification, Third revision Bureau of Indian standards, New Delhi, India.

[8] IS 383:1970, Specification for coarse aggregate and fine aggregate from Natural sources for concrete (Reaffirmed 1997), Bureau of Indian Standards, New Delhi, India.

[9] IS 2386-1968, Methods of tests for hydraulic Cement, Bureau of Indian Standards, New Delhi, India.

[10] IS 3025:1986, Method of Sampling and Test (physical and chemical) for Water and Waste water", Bureau of Indian Standards, New Delhi.

[11] IS 10262:2009, Concrete mix proportions guidelines, First revision Bureau of Indian standards, New Delhi, India.

[12] M.S. Shetty, "Concrete Technology-Theory and practice", Chand S. and Co. Ltd, 2004, India.

[13] M. Vijaya Sekhar Reddy, I. V. Ramana Reddy, "Studies On durability characteristics of high performance concrete", International Journal of advanced Scientific and technical research, Vol.2(6), 2012, p.226-234

[14] IS 516:1959, Method of Test For Strength Of Concrete (Reaffirmed 1999), Bureau of Indian Standards, New Delhi, India.

[15] M. G. Shaikh and S. A. Daimi ," Durability studies of concrete made by using artificial sand with dust and natural sand”, International Journal Earth science and Engineering, Vol.4(6), 201, p.823-825.

\section{AUTHOR PROFILE}

P.Bhanu Prakash Reddy, holds PG from GITAM University, Visakhapatnam, India. His interested research area is construction materials.

V.Sowjanya Vani, holds Ph.D from Andhra University, Visakhapatnam, India and has a total experience of 9 year in teaching. Her research areas include reuse of waste material into concrete and concrete exposed to high temperatures.

N.Sunil, holds M.Tech from National Institute of Technology, Warangal, India. He has a total experience of 4.7 years in teaching. His research areas include construction management and advance construction materials. 